\title{
Evaluating the Effects of In-situ Rainwater Harvesting Techniques on Soil Moisture Conservation and Grain Yield of Maize (Zea mays L.) in Fedis District, Eastern Hararghe, Ethiopia
}

\author{
Amisalu Milkias ${ }^{*}$, Teshale Tadesse ${ }^{2}$, Habtamu Zeleke ${ }^{3}$ \\ ${ }^{1}$ Department of Natural Resource Management, Haramaya University, P.O. Box, 138, Dire Dawa, Ethiopia \\ ${ }^{2}$ College of Agriculture and Natural Resource, Mizan-Tepi University P. O. Box 260, Mizan Teferi, Ethiopia \\ ${ }^{3}$ Departement of Plant Science, Haramaya University, P.O. Box, 138, Dire Dawa, Ethiopia
}

\section{A R T I C L E I N F O}

\section{Research Article}

Received 05 February 2018

Accepted 05 August 2018

\section{Keywords.}

In-situ rainwater harvesting

Soil moisture

Contour ridge

Tied ridge

Ridge furrow

\section{*Corresponding Author:}

E-mail: amsalumilkias@yahoo.com

\begin{abstract}
A B S T R A C T
In the drier farming regions of the world, where crop production is constrained by short growing period, unpredictable and short rainfall with sporadic run-off, in-situ rainwater harvesting is vital for successful crop production. In connection to this, a study was conducted in Fedis district of Oromia region during the main rainy seasons of 2015 and 2016 to evaluate the effects of in-situ rainwater harvesting techniques (Ridge Furrow (RF), Contour Ridge (CR), and Tied Ridge (TR)) on soil moisture conservation and grain yield of maize. A spilt-plot design was used and soil moisture content was measured at three growth stages of the crop to a depth of $60 \mathrm{~cm}$ with $20 \mathrm{~cm}$ interval. The results showed that water harvesting techniques significantly increased moisture conservation compared to the control, which was flat bed preparation. Averaged over the three stages, the TR, CR and RF treatments increased soil moisture storage by $134.59,128.57$, and $121.87 \%$, respectively, compared to the control. The study also revealed that the in-situ rainwater harvesting techniques, due to the improved soil moisture storage, significantly affected grain yield of the maize. Averaged over the two years, the TR, CR, and FR increased the grain yield $143.14,131.47$ and $121.16 \%$, respectively, over the control treatment. Therefore, in drier environments, such as Fedis, in-situ rainwater harvesting techniques can be recommended for better moisture conservation and subsequent improvement in crop production.
\end{abstract}

DOI: https://doi.org/10.24925/turjaf.v6i9.1129-1133.1839

\section{Introduction}

Agriculture is the major economic activity for SubSaharan Africa countries, and it is strongly considered as the backbone of these countries' economic development and their people's wellbeing in the future (Giller et al., 2009). Rapid population growth occurs in developing countries with a significant proportion still depending on a predominantly rain fed-based economy. Unfortunately, in several regions, including Africa in general and Ethiopia in particular, rain fed agriculture has generally been associated to low yield levels, and high on-farm water losses. As result the majority of the people are not able to ensure their food security. Low crop productivity, food insecurity, hunger and malnutrition characterize poor rural smallholder agriculture based community (Bekele, 1998).

From the $41 \%$ of semi-arid region of Sub-Saharan Africa farming land, only about $2 \%$ of the arable lands are irrigated, that is, rain fed agriculture is the dominant crop production system to meet the food demand (Zougmore et al., 2002). However, the unreliability in rainfall and recurrent droughts lead to subsequent production failures and puts great pressure on the food self-sufficiency of the region. The low soil water retention capacity or the high potential evapotranspiration rate is the major problem.

In-situ rain water harvesting techniques such as tied ridge (TR), furrow ridge (FR) and contour ridge (CR) are an effective practice particularly in lands with slopes less than 3-4\% and by adding terrace on steeper slopes (Moldenhauer and Onstand, 1977) in increasing crop yields by increasing the time for the water to penetrate into the soil. Heluf Gebrekidan and Yohannes Uloro (2002) observed maize yield increments of 15 to $50 \%$ due to tied ridges and 15 to $38 \%$ for sorghum in eastern Ethiopia. Asfaw Belay et al. (1998) reported maximum 
maize yield increases of 10, 18 and $23 \%$ on Entisols and 54, 35 and $26 \%$ on Vertisols of eastern Ethiopia, with crop residue, with residual NP and with both crop residue and residual NP, respectively, due to the combinations of tied ridges and furrow planting over flat bed Planting.

Among the environmental problems people in eastern lowlands of Ethiopia are vulnerable to soil moisture stress problem and there have been notable droughts in this part of the country throughout human history (Tadesse et al., 2008; UNEP, 2006; Gebre-Michael and Kifle, 2009). Some studies have been done on the effectiveness of micro-basin tillage to improve soil moisture in different parts of the semiarid areas in highlands of Ethiopia (Gebreyesus, 2012; McHugh et al., 2007; Heluf, 2003; Aklilu and Mekiso, 2015). Except, Aklilu and Mekiso (2015), all of the studies were at the highlands. However, the same problem (soil moisture stress) is happening in low lands of Eastern Hararghe. This indicates that there were less or no studies done to identify suitable in-situ rainwater harvesting techniques to solve crop production problem. Hence this study was carried out in Fedis district, Eastern Hararghe, Ethiopia. The objective of this study was to evaluate the effect of in-situ rainwater harvesting structures on soil moisture conservations and grain yield of maize.

\section{Materials and Methods}

\section{Description of The Study Area}

The field experiment was conducted during the main rainy season (May to October) of 2015 and 2016 in eastern Ethiopia, at Fedis research sub- station of Haramaya University. Fedis is one of the woreda's of eastern Hararghe Zone in the semi-arid belt of the eastern low lands in the Oromiya regional state. The station is located west of Boko town in the semi-arid area of Fedis woreda. Climatically, the district is classified into Woinadega $(15 \%)$ and kola $(85 \%)$ agro climatic zones. The area is characterized by bimodal rainy seasons, "Belg" and "Meher". The "Belg" season is between March and May, and the second main rainy season is "Meher" which extends from July to October (Fedis Woreda Office of Agriculture). The site is situated at $9^{\circ} 07^{\prime} \mathrm{N}$ Latitude and $42^{\circ} 4^{\prime} \mathrm{E}$ Longitude with an altitude of 1702 meters above sea level (GPS measurement). In the study area, the mean annual maximum and minimum temperature was $27.8^{\circ} \mathrm{C}$ and $8.8^{\circ} \mathrm{C}$, respectively, and the area had annual rainfall of $714.3 \mathrm{~mm}$ (Fedis Agricultural Research Centre).

\section{Treatments and Experimental Design}

Field experiments were conducted at Fedis, Haramaya University Research Station to investigate the effects of in-situ rainwater harvesting techniques on soil moisture conservation and grain yield of maize. The field experiments were conducted with the application of recommended rates of $\mathrm{N}$ and $\mathrm{P}$ fertilizers. Throughout the study period, each experiment was laid down in a spiltplot design with three replications. The treatments considered were contour ridge (CR), tied ridge (TR), ridge furrow $(\mathrm{RF})$ and flat bed planting $(\mathrm{FBP})$, which is control.
The improved maize variety Melkasa- 4 was used as a test crop on all of the two sets of trials where by planting was made at the main cropping season in the end of May. The crop was planted on a plot size of $5 \mathrm{~m} \times 4.5 \mathrm{~m}$ $\left(22.5 \mathrm{~m}^{2}\right)$ in rows of six per plot at a spacing of 75 by 30 $\mathrm{cm}$. The recommended rate of fertilizer applied for the crop on the plots were $92 \mathrm{~kg} \mathrm{~N}$ and $40 \mathrm{~kg}$ P/ha. Half of the rate of $\mathrm{N}$ and the full rate of the $\mathrm{P}$ fertilizers were applied $5 \mathrm{~cm}$ below the seed at time of planting as urea $(46 \% \mathrm{~N})$ and as triple super phosphate or TSP (20\% P), respectively. Whereas the second half of the $\mathrm{N}$ fertilizer was applied 30-40 days after planting at 7-10 $\mathrm{cm}$ away from the plant as two side dressing at about $5 \mathrm{~cm}$ below the surface.

\section{Data Collection and Statistical Analysis}

The soil moisture content data was collected from three depths $(0-20 \mathrm{~cm}, 20-40 \mathrm{~cm}$ and $40-60 \mathrm{~cm})$ at three growth stages (stage one is vegetative stage (at the end of June); stage two is Flowering and fertilization stage (at the end of August); and stage three is Grain filling and maturity stage (at the end of September)), and determined in the form of depth $(\mathrm{mm})$ of water stored in the top 0.6 meter soil depth (assumed to be the depth of the effective rooting zone). The soil water stored (\%) in each $0.2 \mathrm{~m}$ incremental depth down to $0.6 \mathrm{~m}$ was determined gravimetrically. It was then expressed in volumetric basis by multiplying by the specific bulk density values measured by the core sampler methods from the respective depths divided by water density as described by Blake (1965). Grain yields and all other desirable data and samples were collected from the four central rows of each plot.

Statistical analysis was conducted for the collected data with the help of SAS software version 9.1. ANOVA was computed and mean differences were made by using least significant difference (LSD) at $\mathrm{P}=0.05$. The results were presented by using tables, figures and text.

\section{Results and Discussions}

The amount of annual rainfall $(\mathrm{mm})$ measured during the experiment years (2015 and 2016) were $724.9 \mathrm{~mm}$ and $883.75 \mathrm{~mm}$, respectively. Rainfall was measured at the Fedis meteorology station, which is $2 \mathrm{Km}$ far from the experiment site (Figure 1).

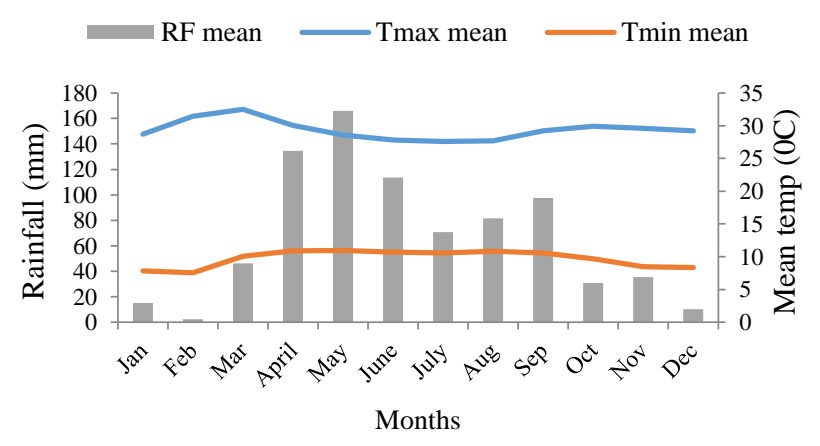

Figure 1 Monthly rainfall and temperature during 2015-2017 in the study area. 
Soil of the experimental site has sandy clay loam texture, moderate total nitrogen content $(0.18 \%)$, low in organic matter $(1.61 \%)$, low organic carbon $(0.93 \%)$, low available phosphorus $\left(1.78 \mathrm{mg} \mathrm{Kg}^{-1}\right)$, and moderately alkaline $\mathrm{pH}$ (7.76) according to the rating of Tekalign (1991), bulk density is $1.33 \mathrm{~g} / \mathrm{cm}^{3}$, field capacity 0.329 and permanent wilting point 0.194 .

\section{The Effect of In-Situ Rainwater Harvesting} Techniques on Soil Moisture Conservations

Soil moisture content (SMC) of the soil profile (60 $\mathrm{cm}$ ) was measured at three periods, i.e. vegetative stage; Flowering and fertilization stage; and grain filling and maturity stage.

The effects of the treatments on SMC are shown in Table 1 and Figure 1 below.
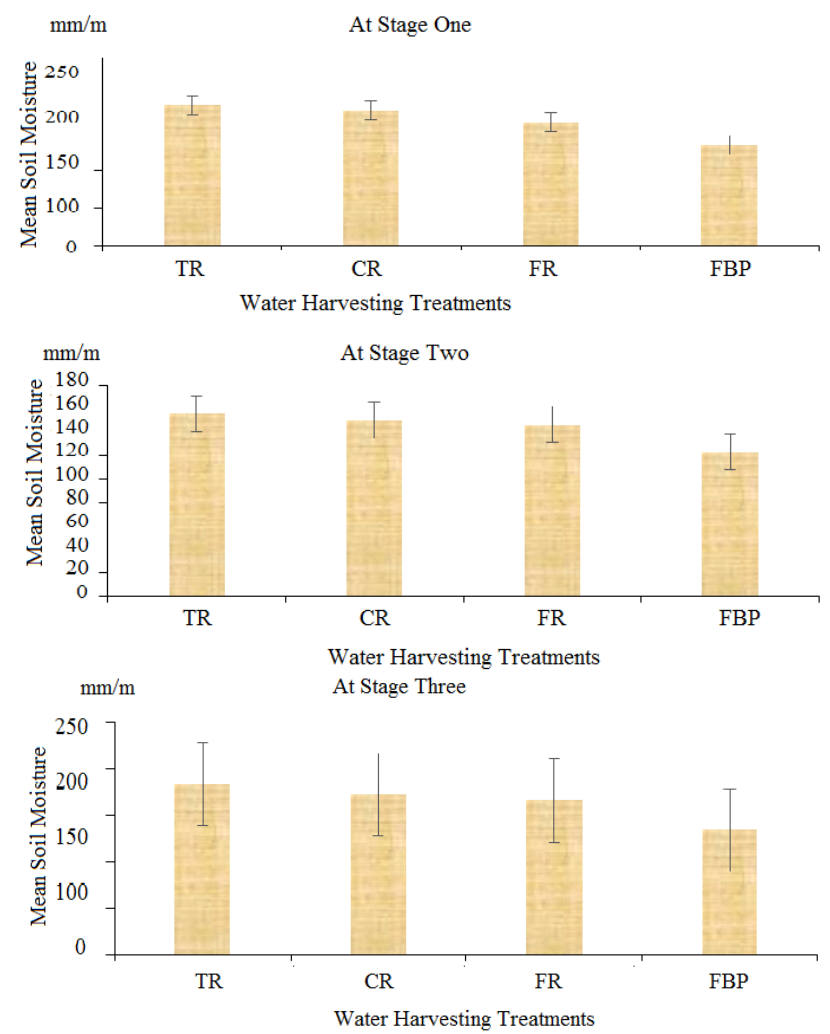

Figure1 The effect of in-situ rainwater harvesting treatments on soil moisture conservations $(\mathrm{mm} / \mathrm{m})$ at three growth stages from effective rooting depth between 2015 and 2017

Table 1 ANOVA summary of the Water harvesting treatments means for soil moisture conservations $(\mathrm{mm} / \mathrm{m})$ at three growth stages from effective rooting depth between 2015 and 2017

\begin{tabular}{l|rrr}
\hline \multirow{2}{*}{ WHT } & \multicolumn{3}{|c}{ Growth Stages } \\
\cline { 2 - 4 } & Stage One & Stage Two & Stage Three \\
\hline TR & $186.74^{\mathrm{a}}$ & $155.52^{\mathrm{a}}$ & $183.62^{\mathrm{a}}$ \\
CR & $180.34^{\mathrm{a}}$ & $149.74^{\mathrm{a}}$ & $172.25^{\mathrm{ab}}$ \\
FR & $163.78^{\mathrm{b}}$ & $146.36^{\mathrm{a}}$ & $166.03^{\mathrm{ab}}$ \\
FBP & $133.47^{\mathrm{c}}$ & $123.03^{\mathrm{b}}$ & $134.21^{\mathrm{b}}$ \\
LSD & 12.48 & 15.27 & 44.64 \\
\hline
\end{tabular}

WHT: Water Harvesting Treatments; LSD0.05 = least significant difference at $5 \%$ level and means followed by the same letter are not significantly different at $\mathrm{P}=0.0$
In all measurement depths at three growth stages, the results obtained showed significant $(\mathrm{P}>0.05)$ difference in SMC between in-situ water harvesting treatments and FBP. Where, in-situ water harvesting treatments (RF, TR and $\mathrm{CR}$ ) recorded SMC values higher than FBP in all depths. This result is in agreement with the findings of Ibrahim (2008), Mohammed (2009), Li et al. (2000), Tian et al. (2003), and McHugh et al. (2007).

In this area, using of the conventional tillage method (FBP) may not help to conserve enough water for crop production, mainly due to the erratic rainfall that induces runoff. High intensity rain showers also enhance water losses through runoff. Crop growth conditions may further be hampered by a number of climatic factors such as, low and erratic rainfall, low humidity levels and high temperature during growing season (Botha et al., 2003).

The water harvested is retained and is far from the evaporative effects but within reach of plant roots. This is because of the presence of heavy textured soil at $40-60 \mathrm{~cm}$ depth (sandy clay) than top $0-20 \mathrm{~cm}$ (sandy clay loam). Lateral flow through which water harvested in the channels could benefit crops can only take place theoretically in the presence of a flow impeding layer at depth. This means water harvested in the channels feeds the soil until it reaches the impervious layer and starts flowing laterally or rising, thereby providing a reservoir of water to the crop at depth which on clays or heavy textured soils, rises by capillarity during dry spells and ensure the crop benefits.

The Effect of In-Situ Rainwater Harvesting Techniques on Grain Yield of Maize

The effect of in-situ rainwater harvesting techniques on grain yield of maize was significantly higher compared to the control at $\mathrm{P}<0.05$.

The effect of in-situ rainwater harvesting structures on the grain yield as presented in Table 2 , at $\mathrm{p}<0.05$, the grain yield has shown significant difference between treatments with rainwater harvesting structures and flat bed planting, which is control in Melkasa 4 variety. TR has resulted in (143.14\%), CR (131.47\%) and FR $(121.16 \%)$ higher grain yield compared to FBP.

All treatments with in-situ rainwater structure have performed much better than the controlled treatments. This might be due to the fact that the water harvesting structures store rainwater in-situ, enhancing infiltration, which provide a reservoir of water to the crop at depth which heavy textured soils (sandy clay), rises by capillarity during dry spells and ensure the crop benefits. This result is in agreement with the finding by Gebreyesus (2012) that tied-ridge and fertilizer, and its interaction significantly influenced the yield and yield components of sorghum and resulted in up to $48 \%$ increment. Tied ridges have been found to be very efficient in storing the rain water, which has resulted in substantial grain yield increase in some of the major dryland crops such as sorghum, maize, wheat, and mungbeans in Ethiopia (Georgis and Takele 2000). The average grain yield increase (under tied ridges) ranged from 50 to over 100 percent when compared with the traditional practice. This increase, however, will vary according to the soil type, slope, rainfall and the crop grown. 


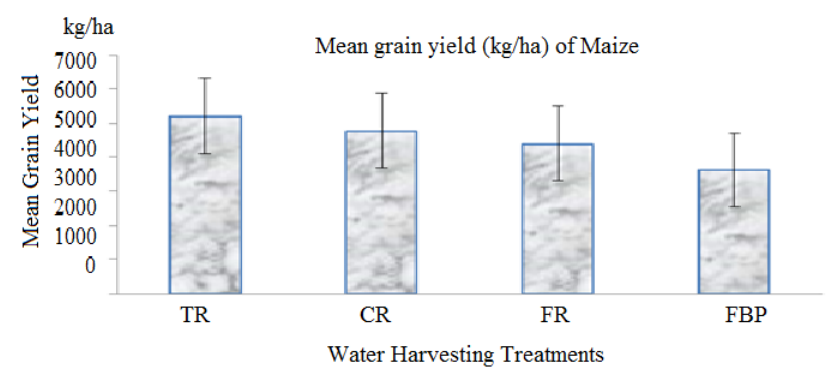

Figure 2 The effect of in-situ rainwater harvesting treatments on grain yield $(\mathrm{kg} / \mathrm{ha})$ of maize (Melkasa 4$)$ grown with different in-situ rainwater harvest treatments between 2015 and 2017 crop seasons

Table 2 ANOVA summary of mean grain yield $(\mathrm{kg} / \mathrm{ha})$ of maize (Melkasa 4) grown with different in-situ rainwater harvest treatments between 2015 and 2017 crop seasons

\begin{tabular}{|c|c|c|c|}
\hline \multirow{2}{*}{ WHS } & \multicolumn{2}{|c|}{ Grain Yield (kg/ha) } & \multirow{2}{*}{$\begin{array}{c}\text { Over all } \\
\text { mean }\end{array}$} \\
\hline & Year I & Year II & \\
\hline TR & 4389 & 6017 & $5203^{\mathrm{a}}$ \\
\hline CR & 4244 & 5314 & $4779^{a}$ \\
\hline FR & 4164 & 4644 & $4404^{\mathrm{ab}}$ \\
\hline FBP & 3362 & 3908 & $3635^{\mathrm{b}}$ \\
\hline LSD & \multicolumn{3}{|c|}{1089} \\
\hline
\end{tabular}

In the current result, the yield of maize was affected by all in-situ rainwater harvesting structures (Figure 2 and Table 2). The work of Heluf (2003) also supports this finding by the fact that the yield response to water conservation treatments was higher both under fertilized and unfertilized conditions than the control treatments.

Among the in-situ rainwater harvesting treatments, TR treatment revealed better performance than CR and FR. The studies in Botswana (Carter and Miller, 1991), Zimbabwe (Pia, 1993; Vogel, 1993), Burkina Faso (Hulugalle and Malton, 1990), USA (Krishna, 1989) and Malawi (Wiyo et al., 2000) have revealed that tied ridging is effective in reducing runoff and increasing soil water storage, which ultimately increase yield of crops. The results of the present study is also in agreement with the findings of (Asfaw et al.,1998), which reported increased yield of Maize as result of planting in the furrows of closed end tied ridges.

\section{Conclusions}

In-situ water harvesting techniques improved soil moisture stored within the root zone as compared to the flat bed planting. Generally, furrow ridge, tied ridge and contour ridge planting produced higher grain yields of maize than flat bed planting. The magnitude of yield response to in-situ water harvesting techniques and the relative effectiveness of the different harvesting methods tend to vary with harvesting techniques. Tied-ridge in-situ rainwater harvesting techniques performed better than other techniques. Finally, it could be recommended that in-situ water harvesting practices are indispensable agricultural operations for successful maize production in Fedis district and any other moisture stressed areas.

\section{Acknowledgement}

The authors would like to acknowledge the Haramaya University for funding this research, since the University is building the bases for development.

\section{References}

Aklilu B, Mekiso Y. 2015. Performance of in-situ rainwater conservation tillage techniques and inorganic fertilizer practices on sorghum production at Ethiopia Somali Region (Kurdha Metan district) International Journal of Agricultural Science Research Vol. 4(5): pp. 098-108.

Asfaw B, Heluf G, Yohannes U. 1998. Effect of tied ridges on grain yield response of Maize (Zea mays L.) to application of crop residue and residual $\mathrm{N}$ and $\mathrm{P}$ on two soil types at Alemaya, Ethiopia, South Africa J. Plant and Soil, 15(4): 123-129.

Carter DC, Miller S. 1991. Three years experience with an onfarm macro-catchment water harvesting system in Botswana, Agricultural Water Management, 19: 191-203.

Gebre MY, Kifle M. 2009. Local Innovation in Climate Change adaptation by Ethiopia pastoralists. Addis Ababa: PROLINNOVA-Ethiopia and Pastoralist Forum (PFE).

Gebreyesus BT. 2012. Effect of Tillage and Fertilizer Practices on Sorghum Production in bergelle.Area, Northern Ethiopia.Momona Ethiopian J. Sci., 4(2): 5269.

Georgis K, Takele A. 2000. Conservation farming technologies for sustaining crop production in semi-arid areas of Ethiopia. In Conservation Tillage for Dryland Farming. Technological options and experiences in Eastern and Southern Africa, eds. E.K. Biamah; J. Rockstrom; G.E. Okwach. RELMA, Workshop Report No. 3, 142-147.

Giller KE, Witter E, Corbeels M, Tittonell P. 2009. Review on Conservation agriculture and smallholder farming in Africa: The heretics' view. Field Crops Research 114: 23-34.

Heluf G. 2003. Grain yield response of sorghum (sorghum bicolor) to tied ridges and planting methods on Entisols and Vertisols of Alemaya area, Eastern Ethiopian highlands journal of agriculture and rural development in the Tropics and Subtropics 104(2):113-128.

Hulugalle NR, Malton PJ. 1990. Effect of rock bunds and tied ridges on soil and water content and sol properties in the Sudan Savannah of Burkina Faso. Tropical Agric, 67(2): 149-153.

Ibrahim OIE. 2008. Effect of in-situ water harvesting on yield and yield components of sorghum (Sorghum bicolor L.) in the north of Gedaref state, Sudan. MSc. Thesis, U. of K.

Krishna JH. 1989. Modeling the effect of tied-ridging on water conservation and crop yields. Agricultural Water Management, 16:87-95

Li, Xiao-Yan, Gong, Jia-Dong, Wei, Xing-Hu. 2000. In-situ rainwater harvesting and gravel mulch combination for corn production in the dry semi-arid region of China. Journal of Arid Environments, 46: 371-382.

McHugh OV, Steenhuis TS, Abebe B, Fernandes ECM. 2007. Performance of in-situ rainwater conservation tillage techniques on dry spell mitigation and erosion control in the drought-prone North Wello zone of the Ethiopian highlands.Science Direct. Soil Tillage Res.,97: 19-36.

Mohammed, Nourelden Abdelrahman Mahmoud. (2009). Effect of Some In-Situ Rain Water Harvesting and Conservation Tillage Techniques on Yield and Yield Components of Sorghum (Sorghum bicolor-L) in the Northern of Gadarif State, Sudan. M Sc. Thesis, University of Gadarif.

Pia MI. 1993. Optimizing fertilizer use and practical rainfall capture in a semi-arid environment with variable rainfall Experiment Agri, 29: 405-415 
Tadesse T, Menghestab H, Gabriel S, Wardlow BD, Knutson CL. 2008. The need for integration of drought monitoring tools for proactive food security management in sub-sahara Africa. Natural Resources Forum, Drought Mitigation Center Faculty Publications.32: 265-279.

Tekalign T. 1991. Soil, plant, water, fertilizer, animal manure and compost analysis. Working Document No. 13. International Livestock Research Center for Africa, Addis Ababa, Ethiopia.

Tian, Yuan, Sua, Derong, Lib, Fengmin, Li, Xiaoling. 2003. Effect of rainwater harvesting with ridge and furrow on yield of potato in semiarid areas. Field Crops Research, 84: 385-391.
UNEP. 2006. Climate Change and Variability in the Sahel Region: Impacts and Unger, P.W., 1984. Tillage Systems for Soil and Water Conservation. FAO Soils Bull FAO Rome, Italy, p. 278.

Vogel H. 1993. Tillage effects on maize yield, rooting depth and soil water content on sandy soils in Zimbabwe, Field Crops Research, 33:367-384.

Wiyo KA, Kasomekera ZM, Feyen J. 2000. Effect of tiedridging on soil water status of a maize crop under Malawi conditions. Agric. Water Management, 45: 101-125.

Zougmoré R, Gnankambary Z, Guillobez S, Stroosnijder L. 2002. Effect of stone rows on soil chemical characteristics under continuous sorghum cropping in semiarid Burkina Faso. Soil Till. Res., 66: 47-53. 